\title{
Purification and Characterization of the Secondary Alcohol Dehydrogenase from Propane-utilizing Mycobacterium vaccae Strain JOB-5
}

\author{
By J. P. COLEMAN AND J. J. PERRY* \\ Department of Microbiology, North Carolina State University, Raleigh, NC 27695, USA
}

(Received 15 May 1985; revised 2 July 1985)

\begin{abstract}
Mycobacterium vaccae strain JOB-5 cultured in the presence of propane contained an inducible secondary alcohol dehydrogenase. The enzyme was purified 198-fold using DEAE-cellulose, $\omega$ aminopentyl agarose and NAD-agarose chromatography. The $M_{\mathrm{r}}$ of the enzyme was approximately 136000 , with subunits of $M_{\mathrm{r}} 37000$. The $\mathrm{pH}$ optimum for the reaction oxidizing propan-2-ol to propanone was $10-10 \cdot 5$ while the optimum for the reverse reaction was $7 \cdot 5-8 \cdot 5$. The isoelectric point was 4.9. NAD but not NADP could serve as electron acceptor. The apparent $K_{\mathrm{m}}$ values for propan-2-ol and NAD were $4.9 \times 10^{-5} \mathrm{M}$ and $2.8 \times 10^{-4} \mathrm{M}$, respectively. The enzyme was inhibited by thiol reagents and metal chelators. It appears to play an essential role in the metabolism of propane by this bacterium.
\end{abstract}

\section{INTRODUCTION}

The growth of Mycobacterium vaccae strain JOB-5 with propane as sole source of carbon and energy involves a subterminal oxidation of propane to propan-2-ol and propanone (Vestal \& Perry, 1969). Subsequent reactions and a $C_{2}+C_{1}$ cleavage produce acetate, which is assimilated through the glyoxylate cycle. The $\mathrm{C}_{1}$ moiety is assimilated through the cellular reduced $C_{1}$ pool (Coleman \& Perry, 1984). Little is known about the enzymes responsible for the series of reactions that convert propane to acetate in this organism. There have been reports on the intermediary metabolism of propanone in other organisms (Taylor et al., 1980), and the pathway apparently differs from that in $M$. vaccae. In order to elucidate the pathway of propane oxidation in $M$. vaccae we have initiated studies on the enzymes involved. Among these is propan-2-ol dehydrogenase, synthesized during growth on propane, an enzyme first reported by Taylor et al. (1980). This report describes the partial purification and characterization of the enzyme. A preliminary report of this work has appeared (Coleman \& Perry, 1983).

\section{METHODS}

Organism and growth conditions. Mycohacterium vaccae strain JOB-5 (ATCC 29678) was grown in a mineral salts medium containing substrate as previously described (Vestal \& Perry, 1969). Large quantities of cells for enzyme purification were obtained by growth in 20 -litre carboys with $0.2 \%$ propan-2-ol $+0.05 \%$ succinate (sodium salt) as substrate. Cells were grown to late-exponential phase, harvested by centrifugation at $4{ }^{\circ} \mathrm{C}$ and washed once in the mineral salts medium followed by centrifugation.

Enzlme purification. All steps were performed at $5{ }^{\circ} \mathrm{C}$. To $80 \mathrm{~g}$ wet weight of cells grown on propan-2-ol was added $160 \mathrm{ml} 50 \mathrm{~mm}-\mathrm{Tris} / \mathrm{HCl}$ buffer, $\mathrm{pH} 8 \cdot 0$. The cells were disrupted by two passes through an Aminco French pressure cell. The lysed cell suspension was homogenized in a blender for $10 \mathrm{~s}$ to decrease viscosity and then centrifuged at $10000 \mathrm{~g}$ for $20 \mathrm{~min}$. To the supernatant fluid (crude extract) was added 0.05 vol. $1 \mathrm{M}^{-\mathrm{MnCl}_{2}}$ to precipitate nucleic acid. After centrifugation at $20000 \mathrm{~g}$ for $20 \mathrm{~min}$, the supernatant fluid was brought to $45 \%$ of saturation by the addition of solid ammonium sulphate. After centrifugation at $12000 \mathrm{~g}$ for $15 \mathrm{~min}$, the supernatant was discarded and the pellet was resuspended in $10 \mathrm{~mm}$ - Tris/ $\mathrm{HCl}$ buffer $\mathrm{pH} 8.0$ (buffer A) and dialysed overnight against 41 of this buffer. The dialysate was centrifuged to remove any precipitate and then applied to a DEAE-cellulose column $(40 \times 5 \mathrm{~cm})$ equilibrated with buffer A. After washing with $200 \mathrm{ml}$ of buffer, the enzyme was eluted with a linear gradient (total volume 1 litre) from 0 to $0.8 \mathrm{M}-\mathrm{KCl}$ in buffer $\mathrm{A}$. Fractions showing highest propan-2-ol dehydrogenase activity were combined and the protein was precipitated by adjusting 
to $75 \%$ of saturation with solid ammonium sulphate. The suspension was centrifuged at $12000 \mathrm{~g}$ for $20 \mathrm{~min}$ and the pellet was resuspended in $50 \mathrm{ml} 10 \mathrm{~mm}$-Tris $/ \mathrm{HCl}$ buffer, $\mathrm{pH} 7 \cdot 0$, containing $0.5 \mathrm{~mm}$-DTT (buffer B). After dialysis overnight against 4 vols buffer $\mathrm{B}$, the solution was applied to an $\omega$-aminopentyl agarose column $(25 \times$ $1.5 \mathrm{~cm}$ ) equilibrated with buffer $\mathbf{B}$. After washing with $100 \mathrm{ml}$ buffer $\mathrm{B}$, the enzyme was eluted with a linear gradient (total volume $600 \mathrm{ml}$ ) from 0 to $0.4 \mathrm{M}-\mathrm{KCl}$ in buffer $\mathrm{B}$. The fractions containing the highest propan-2-ol dehydrogenase activity were combined and applied to a type 3 NAD-agarose column (NAD linked to agarose via the $\mathrm{C} 8$ of the purine ring). The column ( $1 \mathrm{ml}$ bed volume) was washed with $50 \mathrm{~mm}-\mathrm{Tris} / \mathrm{HCl}$ buffer, $\mathrm{pH} 8.0$, containing $0.1 \mathrm{mM}$-DTT and $0.5 \mathrm{M}-\mathrm{KCl}$ (buffer $\mathrm{C}$ ) until no more protein (measured as $A_{280}$ ) was present in the effluent. Enzyme was then eluted with $1 \mathrm{~mm}-\mathrm{NAD}$ in buffer $\mathrm{C}$ and the solution was passed through a column of Bio-Gel P-6DG (Bio-Rad) to remove NAD, using buffer $\mathrm{C}$ as eluent.

Enzyme assay. Propan-2-ol dehydrogenase was assayed spectrophotometrically by following the alcoholdependent reduction of NAD at $340 \mathrm{~nm}$. The standard reaction mixture contained, in a final volume of $1 \mathrm{ml}$ : HEPES buffer, pH 8.5, $40 \mu \mathrm{mol}$; NAD, $2 \mu \mathrm{mol}$; propan-2-ol, $5 \mu \mathrm{mol}$; and a suitable amount of enzyme. Reactions were initiated by the addition of substrate. One unit of activity is defined as that amount of enzyme required to reduce $1 \mu \mathrm{mol} \mathrm{NAD} \min ^{-1}$ at $30^{\circ} \mathrm{C}$. Protein concentrations were determined by the method of Bradford (1976) using bovine serum albumin as a standard.

Electrophoresis. Samples were taken from stages in the purification of the propan-2-ol dehydrogenase and subjected to electrophoresis in $7.5 \%(\mathrm{w} / \mathrm{v})$ cylindrical polyacrylamide gels. The general procedure of Davis (1964) was used with the buffer system of Laemmli (1970), omitting SDS. Propan-2-ol dehydrogenase activity was located by incubating the gel for $30 \mathrm{~min}$ in the dark at room temperature in a solution containing the following (per $10 \mathrm{ml})$ : $400 \mu \mathrm{mol}$ HEPES, pH $8.5 ; 10 \mu \mathrm{mol}$ propan-2-ol; $5 \mu \mathrm{mol} \mathrm{NAD;} 6 \mu \mathrm{mol}$ nitroblue tetrazolium; and $1.2 \mu \mathrm{mol}$ phenazine methosulphate. Regions containing propan-2-ol dehydrogenase appeared as dark formazan bands on a clear background. Protein was stained by immersion of the gels in 0.25\% Coomassie Brilliant Blue R-250 in $40 \%$ $(\mathrm{v} / \mathrm{v})$ methanol $/ 10 \%(\mathrm{v} / \mathrm{v})$ glacial acetic acid for at least $4 \mathrm{~h}$. Gels were destained in $40 \%(\mathrm{v} / \mathrm{v})$ methanol/10\% $(\mathrm{v} / \mathrm{v})$ glacial acetic acid.

SDS-PAGE electrophoresis was done on $12 \%(\mathrm{w} / \mathrm{v})$ polyacrylamide slab gels $(150 \times 1.5 \mathrm{~mm})$ according to the procedure of Fairbanks et al. (1971).

Standard proteins of $M_{\mathrm{r}} 14400-92500$ were used as markers and gels were stained as described above. Densitometer scans of stained gels were obtained using a Gilford spectrophotometer equipped with a gel scanning unit.

Isoelectric focusing. Polyacrylamide gel isoelectric focusing was performed as described by Righetti \& Drysdale (1971) with the following modifications. Enzyme samples containing 1-5 $\mu \mathrm{g}$ protein in a $1 \%(\mathrm{w} / \mathrm{v})$ solution of carrier ampholyte containing $20 \%(\mathrm{w} / \mathrm{v})$ sucrose were layered onto cylindrical $5 \%(\mathrm{w} / \mathrm{v})$ polyacrylamide gels $(100$

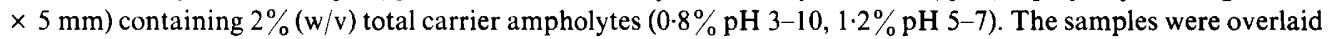
with $100 \mu 10 \%(\mathrm{w} / \mathrm{v})$ sucrose. The remaining space in each tube was filled with upper buffer solution. The upper and lower buffers were $10 \mathrm{~mm}$-histidine and $10 \mathrm{~mm}$-glutamic acid, respectively. A control tube loaded with horse spleen ferritin (pI range $4 \cdot 2-4 \cdot 3$ ) was used to visually monitor the progress of the run. After electrophoresis at $8^{\circ} \mathrm{C}$ for $6-8 \mathrm{~h}$ at a constant power of $5 \mathrm{~W}$, the gels were removed from the tubes and sliced into $5 \mathrm{~mm}$ segments. Each segment was placed in a vial containing $1 \mathrm{ml}$ degassed $5 \mathrm{~mm}-\mathrm{KCl}$ and incubated at $4{ }^{\circ} \mathrm{C}$ overnight. The pH of each sample was determined with a combination electrode. Enzyme activity was located in gels prepared in an equivalent manner by incubating them in the dehydrogenase stain described.

$M_{\mathrm{r}}$ determination. The $M_{\mathrm{r}}$ of the purified propan-2-ol dehydrogenase was estimated by gel filtration according to the method of Andrews (1964) using a Sephadex G-200 column $(74 \times 2.5 \mathrm{~cm})$. The elution buffer was $0 \cdot 1 \mathrm{M}-\mathrm{NaCl}$, $0.5 \mathrm{M}$-Tris $/ \mathrm{HCl}, \mathrm{pH} 7 \cdot 5$. Blue Dextran 2000 was used to determine the void volume of the column. The marker proteins were catalase, aldolase, bovine serum albumin and ovalbumin. Eluent was monitored at $280 \mathrm{~nm}$ to determine marker protein position and assayed for enzyme activity to locate the propan-2-ol dehydrogenase.

Identification of reaction products. A Hewlett-Packard $5880 \mathrm{~A}$ gas chromatograph equipped with a flameionization detector was used to identify and quantify the product of the dehydrogenase reaction. Samples $(1 \mu \mathrm{l})$ from the standard reaction mix (propan-2-ol as substrate) were removed at selected time intervals and injected directly onto a glass column $(6.5 \mathrm{~mm} \times 3 \mathrm{~m})$ packed with $5 \%$ Carbowax 20 M on 80/120 Carbopack B (Supelco). Product retention times and peak areas were compared with those of standard compounds. Column temperature was $100^{\circ} \mathrm{C}$. Injection and detector temperature were $225^{\circ} \mathrm{C}$. Carrier gas $(\mathrm{He})$ flow rate was $25 \mathrm{ml} \mathrm{min}^{-1}$. The amount of NADH present at sampling time was estimated from the absorbance at $340 \mathrm{~nm}\left(\varepsilon=6.2 \times 10^{3} \mathrm{M}^{-1}\right.$ $\left.\mathrm{cm}^{-1}\right)$.

\section{RESULTS}

Effect of growth substrate on activity of the propan-2-ol dehydrogenase. The propan-2-ol dehydrogenase was present at very low specific activities (0.008-0.015 units per mg protein) in extracts of cells following growth on propan-l-ol, succinate, propionate or acetate. Growth with 
Table 1. Purification of propan-2-ol dehydrogenase of M. vaccae JOB-5

The starting material was $80 \mathrm{~g}$ (wet weight) of cells grown on $0.2 \%$ propan-2-ol $+0.05 \%$ sodium succinate.

\begin{tabular}{lcccccc}
\multicolumn{1}{c}{ Purification step } & $\begin{array}{c}\text { Volume } \\
(\mathrm{ml})\end{array}$ & $\begin{array}{c}\text { Total } \\
\text { activity } \\
\text { (units) }\end{array}$ & $\begin{array}{c}\text { Total } \\
\text { protein } \\
(\mathrm{mg})\end{array}$ & $\begin{array}{c}\text { Specific } \\
\text { activity } \\
\text { [units (mg } \\
\text { protein) }\end{array}$ & $\begin{array}{c}\text { Purification } \\
\text { factor }\end{array}$ & $\begin{array}{c}\text { Yield } \\
(\%)\end{array}$ \\
Crude extract & 192 & 160 & 1800 & $0 \cdot 089$ & $1 \cdot 0$ & 100 \\
Ammonium sulphate $(0-45 \%$ sat.) & 60 & 104 & 804 & $0 \cdot 196$ & $2 \cdot 2$ & 65 \\
DEAE-cellulose & 41 & 66 & 208 & $0 \cdot 278$ & $3 \cdot 1$ & 41 \\
W-Aminopentyl agarose & 61 & 47 & 69 & $0 \cdot 792$ & $8 \cdot 9$ & 20 \\
NAD-agarose & & $35 \cdot 1$ & 2 & $17 \cdot 6$ & $198 \cdot 0$ & 15
\end{tabular}

propan-2-ol, propanone or propane as substrate resulted in 10-fold higher levels of propan-2-ol dehydrogenase.

Purification of enzyme. The final enzyme preparation had a specific activity 198 -fold higher than that in crude extracts and represented a yield of $15 \%$. A loss of enzyme after DEAEcellulose chromatography was tolerated since this step removed a large amount of uncharacterized contaminating material which interfered with the binding of the enzyme to the $\omega$-aminopentyl agarose column. The material eluting from the $\omega$-aminopentyl agarose column at salt concentrations between 85 and $135 \mathrm{~mm}$ contained enzyme activity. A large protein peak eluting before the propan-2-ol dehydrogenase and partially overlapping it was the major contaminant in the combined active fractions. This protein was separated from the propan-2-ol dehydrogenase using an NAD-agarose column. The purification steps and yields are presented in Table 1. Preliminary screening experiments with affinity supports such as Cibacron Blue F3G-A agarose and Procion Red agarose indicated that the enzyme did not bind to these ligands.

PAGE at pH 8.8 was used to assess enzyme purity. The major protein band corresponded to alcohol dehydrogenase activity. Scans of stained gels at $595 \mathrm{~nm}$ indicated the presence of two minor bands, both migrating more slowly than alcohol dehydrogenase and representing approximately $5 \%$ of the total protein, as judged by the peak areas of the stained gel scans. Thus the final preparation of alcohol dehydrogenase appeared to be approximately $95 \%$ homogeneous.

$M_{\mathrm{r}}$ and subunit composition. After three independent determinations, the $M_{\mathrm{r}}$ of the enzyme was estimated to be $136000 \pm 5000$ by gel filtration. SDS-PAGE of the enzyme showed a single protein band corresponding to an $M_{\mathrm{r}}$ of 37000 , suggesting that the enzyme is a tetramer, constructed from identical subunits.

Isoelectric point. A single band of activity, corresponding to an isoelectric point of $4.9 \pm 0 \cdot 1$, appeared after staining isoelectric focusing polyacrylamide gels for propan-2-ol dehydrogenase.

Reaction products. Gas chromatographic analyses of the standard reaction mixture (propan-2ol as substrate) at timed intervals indicated that propanone accumulated concomitantly with the formation of equimolar amounts of NADH. No other products were detected.

$p H$ dependence of the reaction rate. The initial velocity of both the forward (propan-2-ol $\rightarrow$ propanone) and reverse reactions over a range of $\mathrm{pH}$ values was tested using the purified enzyme. Both reactions occurred to some extent over a fairly broad $\mathrm{pH}$ range with the optimum for the forward reaction between 10 and $10 \cdot 5$ and for the reverse reaction between $7 \cdot 5$ and 8.5.

Substrate specificity. The purified enzyme oxidized both primary and secondary alcohols (Table 2). The primary alcohols had $K_{\mathrm{m}}$ values at least two orders of magnitude higher than those for secondary alcohols. In this regard the enzyme can best be described as a secondary alcohol dehydrogenase. Among the secondary alcohols, the highest $V_{\max }$ was seen with butan-2ol and the lowest $K_{\mathrm{m}}$ with propan-2-ol. The following substrates were tested at concentrations of $30 \mathrm{~mm}$ (or at their highest solubility if lower than $30 \mathrm{~mm}$ ) and were not oxidized: methanol, 
Table 2. Specificity of the purified propan-2-ol dehydrogenase from M. vaccae strain JOB-5 for various alcohol substrates

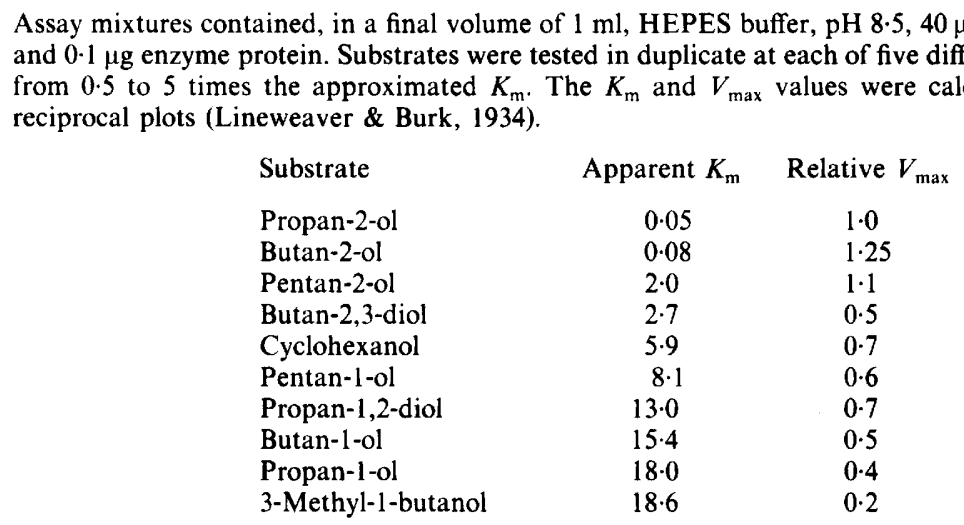

\section{Table 3. Kinetic parameters of the dehydrogenase reaction}

Kinetic parameters are shown for the forward and reverse reactions. Reaction mixtures contained, in a final volume of $1 \mathrm{ml}$ : HEPES buffer, pH $8.5,40 \mu \mathrm{mol}$; enzyme, $0 \cdot 1 \mu \mathrm{g}$; $\mathrm{NAD}^{+}$or NADH; propan-2-ol or propanone. Reactions were initiated by addition of propan-2-ol or propanone and the rate of $\mathrm{NAD}^{+}$ reduction or NADH oxidation was monitored spectrophotometrically at $340 \mathrm{~nm}, 30^{\circ} \mathrm{C}$.

\begin{tabular}{|c|c|c|}
\hline Substrate & $\begin{array}{l}K_{\mathrm{m}} \\
(\mathrm{M})\end{array}$ & $\begin{array}{c}\text { Dissociation const } \\
\text { (M) }\end{array}$ \\
\hline Propan-2-ol & $4.9 \times 10^{-5}$ & $4.8 \times 10^{-5}$ \\
\hline Propanone & $3.0 \times 10^{-4}$ & $3.1 \times 10^{-4}$ \\
\hline NAD & $2.8 \times 10^{-4}$ & $2.2 \times 10^{-4}$ \\
\hline NADH & $1.5 \times 10^{-4}$ & $1.7 \times 10^{-4}$ \\
\hline
\end{tabular}

ethanol, ethylene glycol, 1,3-propanediol, 1,3-dichloro-2-propanol, glycerol, 3-hydroxypyruvate, 3-hydroxybutyrate, tert-butanol, 2-hexanol, 3-hexanol, 2-heptanol, 4-heptanol, benzyl alcohol, phenylethyl alcohol, acetol, cyclopentanol, cyclooctanol, cyclodecanol, cyclohexanediols $(1,3-$, 1,2- and 1,4-); methylcyclohexanols (2-, 3- and 4-); dimethylcyclohexanols (2,3- and 2,6-); dicyclopropyl methanol; and 3-cyclohexyl-1-propanol.

The enzyme could use NAD as an electron acceptor but not NADP. The following compounds were also tested and none could serve as electron acceptor: FMN, FAD, cytochrome $c$ (horse heart), phenazine methosulphate and 2,6-dichlorophenolindophenol.

Kinetic parameters. The kinetic parameters of both the forward (NAD reduction) and reverse reactions were evaluated with propan-2-ol and propanone as the respective substrates. All conditions except the substrate concentrations were as described for the standard assay. Data obtained from duplicate assays at five different subsaturating concentrations of each of the reactants in both the forward and reverse directions were plotted according to Lineweaver \& Burk (1934). The intercepts of the family of intersecting lines obtained were replotted according to Dalziel (1957). The $K_{\mathrm{m}}$ values and dissociation constants for the two reactions are reported in Table 3. The $K_{\mathrm{m}}$ values and dissociation constants are quantitatively indistinguishable given the error involved in the measurements. An ordered mechanism is apparent, but other tests are required to ascertain the particular class of reaction.

Effect of mono- and divalent cations on propan-2-ol dehydrogenase activity. No stimulation of enzyme activity was observed in the presence of the following cations, each at $1 \mathrm{mM}$, added to the standard reaction mixture as their sulphate salts: $\mathrm{Na}^{+}, \mathrm{K}^{+}, \mathrm{NH}_{4}^{+}, \mathrm{Ca}^{2+}, \mathrm{Mg}^{2+}, \mathrm{Co}^{2+}, \mathrm{Cu}^{2+}$, $\mathrm{Mn}^{2+}$ or $\mathrm{Zn}^{2+}$. 
Table 4. Effect of various compounds on the activity of the purified propan-2-ol dehydrogenase from $M$. vaccae strain JOB-5

The standard assay was used with $0 \cdot 1 \mu \mathrm{g}$ enzyme protein per assay. The reaction mixture containing all components except NAD and propan-2-ol was incubated in the dark for $10 \mathrm{~min}$ at $30^{\circ} \mathrm{C}$. The reaction was started by the addition of NAD and propan-2-ol and the rates were compared with those of a control with no inhibitor present.

\begin{tabular}{|c|c|c|}
\hline Compound & $\begin{array}{l}\text { Final concn } \\
(\mathrm{mM})\end{array}$ & $\begin{array}{l}\text { Percentage } \\
\text { inhibition }\end{array}$ \\
\hline 1,10-Phenanthroline & $\begin{array}{l}0.05 \\
0 \cdot 1 \\
1 \cdot 0\end{array}$ & $\begin{array}{r}32 \\
45 \\
100\end{array}$ \\
\hline 2,2'-Dipyridyl & $\begin{array}{l}0.5 \\
1 \cdot 0 \\
3 \cdot 0\end{array}$ & $\begin{array}{r}3 \\
22 \\
43\end{array}$ \\
\hline 8-Hydroxyquinoline & $\begin{array}{l}0.5 \\
1.0\end{array}$ & $\begin{array}{l}51 \\
77\end{array}$ \\
\hline EDTA & $20 \cdot 0$ & 0 \\
\hline $\mathrm{KCN}$ & $\begin{array}{l}0 \cdot 01 \\
0 \cdot 1\end{array}$ & $\begin{array}{l}0 \\
6\end{array}$ \\
\hline $\mathrm{NaN}_{3}$ & $300 \cdot 0$ & 8 \\
\hline Semicarbazide & $\begin{array}{l}0 \cdot 1 \\
1 \cdot 0 \\
3 \cdot 0\end{array}$ & $\begin{array}{r}0 \\
27 \\
55\end{array}$ \\
\hline 4-Hydroxymercuribenzoic acid & $\begin{array}{l}1.0 \times 10^{-3} \\
3.0 \times 10^{-3} \\
1.0 \times 10^{-2}\end{array}$ & $\begin{array}{r}10 \\
63 \\
100\end{array}$ \\
\hline Iodoacetate & $\begin{array}{r}1 \cdot 0 \\
10 \cdot 0 \\
17 \cdot 5\end{array}$ & $\begin{array}{l}27 \\
47 \\
77\end{array}$ \\
\hline Blue Dextran 2000 & $2.5 \times 10^{-2 *}$ & 0 \\
\hline
\end{tabular}

* Final dye concentration, using $\varepsilon=13.6 \mathrm{~mm}^{-1} \mathrm{~cm}^{-1}$ for Cibacron Blue F3GA at $610 \mathrm{~nm}$ (Ticha et al., 1978).

Inhibition of enzyme. The enzyme was strongly inhibited by metal-complexing agents $(1,10-$ phenanthroline, 2,2'-dipyridyl, and 8-hydroxyquinoline) and thiol reagents (4-hydroxymercuribenzoic acid and iodoacetate), as well as by the carbonyl reagent semicarbazide (Table 4). No inhibition was seen in the presence of Blue Dextran 2000 even at NAD concentrations of onefifth its $K_{\mathrm{m}}$.

\section{DISCUSSION}

The presence of a secondary alcohol dehydrogenase in crude extracts of $M$. vaccae strain JOB5 following growth on propane supports the proposed pathway for propane metabolism via propan-2-ol (Vestal \& Perry, 1969). The data indicate that the enzyme is inducible, appearing at significant levels only after growth of the organism on propane, propan-2-ol, or propanone. The low activity of this enzyme in extracts of cells following growth in the presence of propan-l-ol also suggests that the enzyme is not involved in the metabolism of propan-l-ol by $M$. vaccae strain JOB-5.

The purified propan-2-ol dehydrogenase from strain JOB-5 differs in several respects from previously described secondary alcohol dehydrogenases. The NAD-dependent secondary alcohol dehydrogenases from Pseudomonas sp. ATCC 21439 (Hou et al., 1979) and a Pichia sp. (Patel et al., 1979) are both smaller in size and are composed of two subunits of equal molecular weight. The enzyme from strain JOB-5, with four subunits, appears to be structurally similar to the NAD-linked secondary alcohol dehydrogenases from Candida boidinii (Schutte et al., 1982), Pseudomonas fluorescens NRRL B-1244 (Hou et al., 1983), the NADP-linked secondary alcohol 
dehydrogenase from Thermoanaerobium brockii (Lamed \& Zeikus, 1981), and the alcohol dehydrogenase from bakers' yeast (Hayes \& Velick, 1954). The isoelectric point of the enzyme from $C$. boidinii (Schutte et al., 1982) is identical to that reported here for the enzyme from strain JOB-5.

The substrate specificities of the previously reported enzymes, however, are different from that of the propan-2-ol dehydrogenase from strain JOB-5. The enzyme from C. boidinii is highly specific for secondary alcohols, with no activity on short-chain primary alcohols (Schutte $e t$ al., 1982). The enzyme from $T$. brockii oxidizes primary alcohols but at much lower $V_{\max }$ values than those calculated for the enzyme from strain JOB-5. In addition, the enzyme from $T$. brockii is specific for NADP as electron acceptor. Both the enzyme from strain JOB-5 and that from Ps. fluorescens (Hou et al., 1983) oxidize a narrow range of secondary alcohols and several primary alcohols. The enzyme from $M$. vaccae, however, does not oxidize methanol and ethanol. A difference is also observed in the $\mathrm{pH}$ optimum for the forward reaction catalysed by these two enzymes. Although chemically this reaction should be favoured at higher $\mathrm{pH}$ values, the enzyme from Ps. fluorescens has a broad yet distinct optimum between $\mathrm{pH} 7$ and $\mathrm{pH} 9$, whereas the enzyme from strain JOB-5 has an optimum between $\mathrm{pH} 10$ and $\mathrm{pH} 10-5$.

With the exception of the enzyme from $T$. brockii, the enzyme from strain JOB- 5 is similar to all of the above-mentioned enzymes in its sensitivity to thiol reagents and metal-chelating agents. The enzyme from $T$. brockii (Lamed \& Zeikus, 1981) was inhibited by thiol reagents but not by metal chelators.

A final distinguishing property of the propan-2-ol dehydrogenase from $M$. vaccae strain JOB5 , which became apparent during the preliminary screening of potential purification procedures, was the absence of binding to Cibacron Blue F3GA-agarose. This type of affinity ligand has found general use in the purification of NAD-linked enzymes and was used in the purification of the enzymes from C. boidinii, T. brockii, Pichia sp., Pseudomonas sp. ATCC 21439 and Ps. fluorescens. No binding of the enzyme from $M$. vaccae strain JOB-5 could be demonstrated using a variety of buffers, $\mathrm{pH}$ values, ionic strengths and flow rates. This observation was further corroborated by the absence of inhibition of the enzyme by Blue Dextran 2000. Possible explanations for these observations are that the Cibacron Blue F3GA moiety either cannot gain access to the dinucleotide fold responsible for NAD binding or that the fold is not present. According to Wilson (1976), 'the absence of marked interaction with Blue Dextran might reasonably be taken as an indication that the dinucleotide fold is not present in the enzymes'. In view of the structural similarities between the enzyme from strain JOB-5 and the other four-subunit enzymes, especially that from bakers' yeast, the absence of a dinucleotide fold would be an interesting feature, considering the evolutionary conservation of the structure (Rosemann et al., 1974; Schultz \& Schirmer, 1974). More specific structural studies are required to resolve this apparent inconsistency.

Paper no. 9564 of the Journal Series of the North Carolina Agricultural Research Service, Raleigh, NC 27695, USA.

\section{REFERENCES}

ANDREWS, P. (1964). Estimation of the molecular weights of proteins by Sephadex gel-filtration. Biochemical Journal 91, 222-233.

BRADFORD, M. M. (1976). A rapid and sensitive method for the quantitation of microgram quantities of protein utilizing the principle of protein-dye binding. Analytical Biochemistry 72, 248-254.

Coleman, J. P. \& Perry, J. J. (1983). Characterization of a secondary alcohol dehydrogenase involved in the growth of Mycobacterium vaccae strain JOB-5 on propane. Abstracts of the Annual Meeting of the American Society for Microbiology, p. 217.

Coleman, J. P. \& Perry, J. J. (1984). Fate of the $\mathrm{C}_{1}$ product of propane dissimilation in Mycobacterium vaccae strain JOB-5. Journal of Bacteriology 160 , 1163-1164.

DALZIEL, K. (1957). Initial steady state velocities in the evaluation of enzyme-coenzyme-substrate reaction mechanisms. Acta chemica scandinavica 11, 17061723.

DAvis, B. J. (1964). Disc electrophoresis. II. Method and application to human serum proteins. Annals of the New York Academy of Sciences 121, 404-427.

Fairbanks, G., Steck, T. L. \& Wallach, D. F. H. (1971). Electrophoretic analysis of the major polypeptides of the human erythrocyte membrane. Biochemistry 10, 2606-2617.

HAYES, J. E. \& Velick, S. F. (1954). Yeast alcohol 
dehydrogenase: molecular weight, coenzyme binding, and reaction equilibria. Journal of Biological Chemistry 207, 225-244.

Hou, C. T., Patel, R. N., Laskin, A. I., Barnabe, N. \& MARCZAK, I. (1979). Identification and purification of a nicotinamide adenine dinucleotide-dependent secondary alcohol dehydrogenase from $C_{1}$ utilizing microbes. FEBS Letters 101, 179-183.

hou, C. T., Patel, R. N., Laskin, A. I., Barist, I. \& BARnABE, N. (1983). Thermostable NAD-linked secondary alcohol dehydrogenase from propanegrown Pseudomonas fluorescens NRRL B-1244. Applied and Environmental Microbiology 46, 98-105.

LAEMMLI, U. K. (1970). Cleavage of structural proteins during the assembly of the head of bacteriophage $T_{4}$. Nature, London 227, 680-685.

LAMED, R. J. \& ZeikUs, J. G. (1981). Novel NADPlinked alcohol-aldehyde/ketone oxidoreductase in thermophilic ethanologenic bacteria. Biochemical Journal 195, 183-190.

LiNEWEAVER, H. \& BURK, D. (1934). The determination of enzyme dissociation constants. Journal of the American Chemical Society 56, 658-666.

Patel, R. N., Hou, C. T., Laskin, A. I., Derelanko, P. \& FELIX, A. (1979). Microbial production of methyl ketones. Purification and properties of a secondary alcohol dehydrogenase from yeast. European Journal of Biochemistry 101, 401-406.

RighetTI, P. \& DRYSDale, J. W. (1971). Isoelectric focusing on polyacrylamide gels. Biochimica et biophysica acta 236, 17-28.

Rosemann, M. G., Moras, D. \& Olsen, K. W. (1974). Chemical and biological evolution of a nucleotidebinding protein. Nature, London 250, 194-199.

Schulz, G. E. \& Schirmer, R. H. (1974). Topological comparison of adenyl kinase with other proteins. Nature, London 250, 142-144.

Schutte, H., Hummel, W. \& Kula, M.-R. (1982). Purification and characterization of a nicotinamide adenine dinucleotide-dependent secondary alcohol dehydrogenase from Candida boidinii. Biochimica et biophysica acta 716, 298-307.

Taylor, D. G., Trudgill, P. W., Cripps, R. E. \& Harris, P. R. (1980). The microbial metabolism of acetone. Journal of General Microbiology 118, 159170.

TiCHA, M., HoRejSI, V. \& Barthova, J. (1978). Affinity electrophoresis of proteins interacting with blue dextran. Biochimica et biophysica acta 534, 5863.

Vestal, J. R. \& Perry, J. J. (1969). Divergent metabolic pathways for propane and propionate utilization by a soil isolate. Journal of Bacteriology 99 , 216-221.

WILson, J. E. (1976). Applications of blue dextran and Cibacron Blue F3GA in purification and structural studies of nucleotide-requiring enzymes. Biochemical Biophysical Research Communications 72, 816-823. 